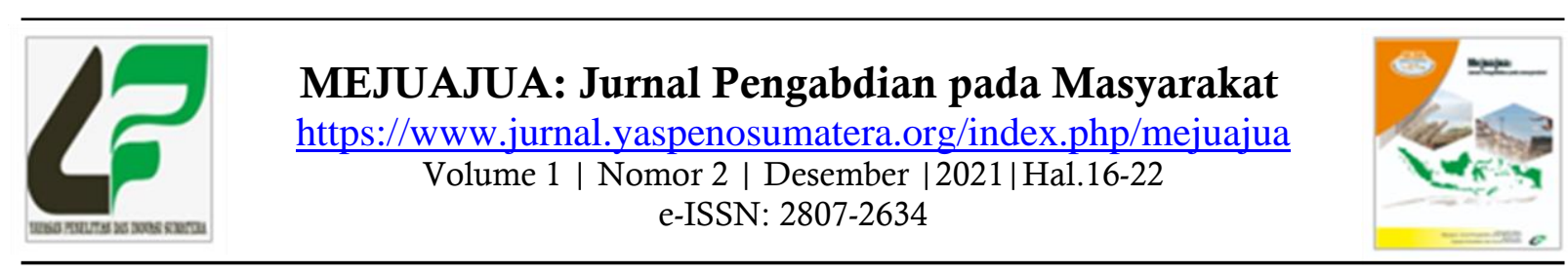

\title{
Pelatihan Produksi Saos Tomat Ibu PKK Lut Tawar dan Pegasing-Aceh Tengah-Nanggroe Aceh Darussalam
}

\author{
Samran $^{1)}$, Suprianto $^{1)}$, Sumardi $^{2}$, Elvy Oktima ${ }^{3)}$, Alam Suhada ${ }^{4)}$, Muhammad Gunawan $^{1)}$, Enny Fitriani $^{1)}$, \\ Herliana $^{1)}$, Sindy Andriani ${ }^{1)}$ \\ ${ }^{1}$ Program Studi Farmasi, Sekolah Tinggi Ilmu Kesehatan Indah, Medan, Indonesia; ${ }^{2}$ Fakultas \\ Farmasi, Universitas Tjut Nyak Dhien, Medan, Indonesia; ${ }^{3}$ Program Studi Farmasi, Sekolah \\ Menengah Kejuruan Al Razi Sinar Harapan, Medan, Indonesia; ${ }^{4}$ Kadis KBP3A Kabupaten Aceh \\ Tengah
}

Keywords :

Produksi, saos, tomat

Corespondensi Author

Emai:ekahasbi@gmail.com

History Artikel

Received: 23-11-2021

Reviewed: 04-12-2021

Revised: $05-12-2021$

Accepted: 05-12-2021

Published: 20-12-2021

DOI:

10.52622/mejuajuajabdimas.v1i2.16

\section{Abstrak.}

Lut Tawar dan Pegasing merupakan dua yang ada di Aceh Tengah, Nanggroe Aceh Darussalam (NAD) sebagai objek Pengabdian oleh Tim PKM Program Studi S1 Farmasi STIKes Indah Medan dan Progran Studi Farmasi SMK Al Razi Sinar Harapan Medan. Ibu anggota TIM PKK utusan Lut Tawar dan Pegasing biasa bersama suami sebagai petani. Ibu yang tergabung dalam TIM PKK berkumpul di Kator Dinas KBP3A untuk dilatih dan dibimbing Tim PKM memproduksi SAOS TOMAT. Tomat salah satu komoditi sayuran asal Aceh Tengah yang saat tertentu panen raya melimpah di Pasar sehingga harga menjadi turun dan berimbas ke kota lain, termasuk Medan, Sumatera Utara; bahkan petani sendiri terkadang tidak lagi memanen karena biaya operasional tidak tercover dari hasil jual panen. Untuk mengatasi ini, alangkah lebih baik bila diolah menjadi SAOS TOMAT sehingga penghasilan petani stabil setiap saat. Ibu-ibu peserta Tim PKK utusan Lut Tawar dan Pegasing mengikuti dengan sangat antusias dan produk SAOS TOMAT sesuai yang diharapkan.

\footnotetext{
This work is licensed under a Creative Commons Attribution 4.0 International

\section{PENDAHULUAN}

Lut Tawar dan Pegasing merupakan dua yang ada di Aceh Tengah, NAD sebagai objek Pengabdian oleh Tim PKM Program Studi S1 Farmasi STIKes Indah Medan dan Progran Studi Farmasi SMK Al Razi Sinar Harapan Medan. Ibu anggota TIM PKK utusan Lut Tawar dan Pegasing biasa bersama suami sebagai petani. Ibu yang tergabung dalam TIM PKK berkumpul di Kator Dinas KBP3A untuk dilatih dan dibimbing Tim PKM memproduksi SAOS TOMAT.

Lut Tawar, kecamatan yang berada di wilayah Aceh Tengah, dengan kekayaan wisata danau Lut Tawar yang menjadi salah satu andalan wisata kabupaten Aceh Tengan. Wisatawan domestik maupun internasional tidak melewatkan keindahan pemandangan yang disajikan anau Lut Tawar(1,2). Suguhan pemandangan danau Lut Tawar yang indah dan menawan karena ada di sekitar dua buah bukit hijau (3) dengan ikan Depik sebagai fauna kekayaan Aceh (4-6).

Sentra produksi tomat Aceh ada di Bener Meriah dan Aceh Tengah yang berada di wilayah Nanggroe Aceh Darussalam (7). Hasil panen sangat dipengaruhi beberapa faktor, diantaranya: iklim dan cuaca, hama dan penyakit, harga dan permintaan pasar (8). Ketiga faktor tersebut sangat besar peranan 
dalam keberhasilan panen tomat di Provinsi Aceh (7). Harga tomat turun drastis seiring panen raya petani tomat di kedua kabupaten Nanggroe Aceh Darussalam, yaitu Aceh Tengah dan Bener Meriah $(9,10)$. Petani rugi bahkan tak sanggup kembalikan modal usaha, karena harga hanya sampai Rp500,per kilogram. Hal ini terjadi raya setiap tahun dan penanganan belum dilakukan untuk antisipasi panen raya tomat dari kedua kabupaten ini, belum ada Pabrik Saos Tomat (10).

Tomat salah satu komoditi sayuran asal Aceh Tengah yang saat tertentu panen raya melimpah di Pasar sehingga harga menjadi turun, sehingga ber-impact negatif terhadap perekonomian masingmasing pribadi petani $(7,10)$. Imbas tidak hanya di kota sekitar, kota Medan Sumatera Utara juga terimbas kondisi ini. Kondisi ini menyebabkan petani menjadi pesimis yang akhirnya tidak lagi memanen tomatnya karena biaya operasional tidak ter-cover dari hasil jual panennya (9). Tomat dibiarkan membusuk di lahan pertanian karena pesimisnya para petani menghadapi kondisi ini (Gambar 1). Untuk mengatasi ini, alangkah lebih baik bila diolah menjadi SAOS TOMAT sehingga penghasilan petani stabil setiap saat, terutama di masa Covid-19.

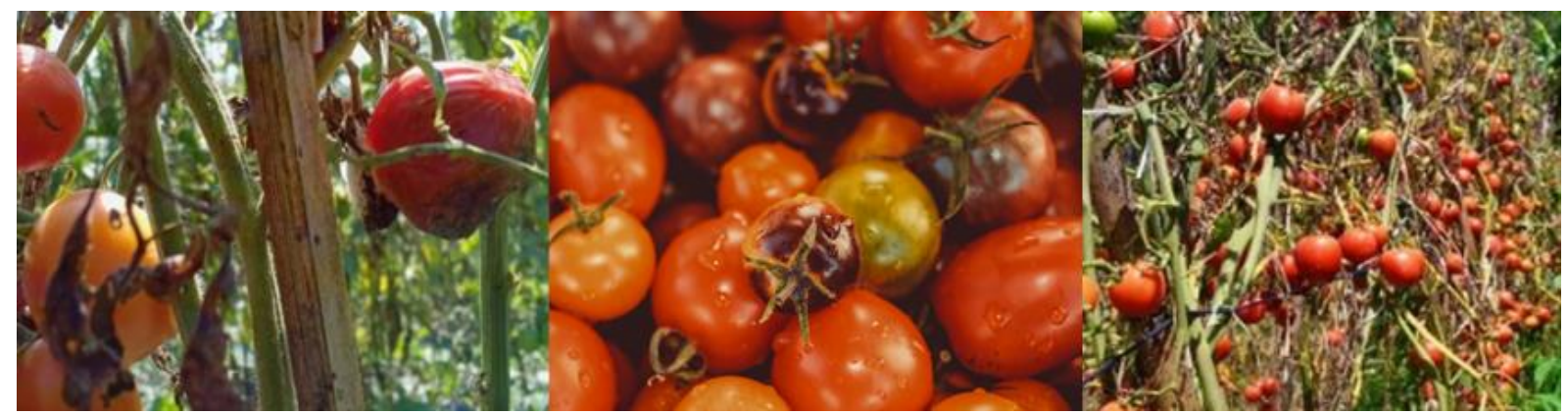

Gambar 1. Tomat dibiarkan membusuk oleh petani di Bener Meriah dan Aceh Tengah

Pelatihan dan bimbingan produsi SAOS TOMAT diharapkan menjadi alternatif solusi lonjakan panen raya tomat yang selama ini menyebabkan ekonomi petani tidak stabil. Kadis KBP3A, bapak Drs H Alam Suhada, MM dalam sambutannya berharap pelatihan dan bimbingan menjadi tonggak peningkatan perekonomian Perempuan Gayo di masa Covid-19. Ketua Tim PKM Dr. Samran, M.Si., Apt. menambahkan bahwa peningkatan taraf hidup masyarakat dapat dilakukan melalui proses pembelajaran yang tepat dan berdaya guna, tentunya belajar yang dapat membantu meningkatan finansial. Salah satunya adalah kegiatan bimbingan dan pelatihan produksi SAOS TOMAT.

SAOS TOMAT mempunyai banyak keunggulan dibandingkan SAOS TOMAT yang berada di pasaran. Keunggulan tersebut adalah tidak digunakan bahan tambahan makanan sintesis, tidak menggunakan pewarna sintesis (11). Pembuatan SAOS TOMAT sangat mudah, murah dengan peralatan sederhana, sehingga dapat diproduksi IRT. Bimbingan dan latihan pembuatan, cara pengemasan dan pemasaran juga sangat diperlukan IRT. Keterampilan produksi SAOS TOMAT berkonstribusi dalam meningkatkan finansial yang akhirnya dapat menstabilkan finansial petani dan meningkatkan taraf hidup keluarga lebih sejahtera (12). Oleh karena itu, perlu dilakukan Pelatihan Produksi SAOS TOMAT bagi IRT yang tergabung dalam kelompok PKK Lut Tawar dan Pegasing, Aceh Tengah, Nanggroe Aceh Darussalam.

\section{METODE}

\section{Survei dan Pendekatan Tim PKM}

Langkah yang dilakukan Tim PKM untuk melaksanakan kegiatan Pelatihan Produksi SAOS TOMAT, yaitu: survay melalui wawancara untuk melihat kondisi masyarakat dan minat maupun antusias Ibu-ibu PKK dalam menaggapi kegiatan PKM. Mengundang Ibu-ibu rumah tangga di bawah kelompok PKK dan anggota keluarga berkumpul di Kantor Kadis KBP3A Aceh Tengah untuk mengikuti bimbingan dan pelatihan. Memberi ceramah keunggulan SAOS TOMAT. Menjelaskan cara pembuatan SAOS TOMAT dengan alat-alat sederhana. Membimbing lansung membuat SAOS TOMAT. Mennyampaikan kalkulasi dana produksi dan harga jual produk. 


\section{Pembuatan Saos Tomat \\ Bahan dan Alat}

Bahan baku terdiri dari tomat, cabe, bawang putih, cuka, gula, garam, natrium benzoat, tepung maizena dan air. Alat yang digunakan terdiri dari: ember plastik, pisau, kuali, penyaring, seperangkat kompor, batang pengaduk kayu, botol pengemas plastik.

\section{Proses Pengolahan}

Tomat disortir, tidak busuk, tidak kisut dan dipilih yang masih segar. Kemudian dicuci sehingga kotoran lenyap dari tomat. lalu direbus atau dikukus bersama cabe. Tomat, cabe dan bawang putih dihaluskan dengan blander $(11,13)$.

\section{Proses Penyaringan}

Bubur tomat, cabe dan bawang putih disaring dan dimasukkan ke dalam kuali yang siap untuk diolah menjadi saos bersama bahan yang lain. Semua filtrat ditambahkan gula sebanyak 1satu kilogram untuk setiap lima kilogram tomat, selanjutnya diaduk sampai semua gula terlarut sehingga diperoleh campuran sempurna $(14,15)$.

\section{Proses Perebusan}

Campuran sempurna ditambahkan tepung maizena, garam, cuka dan pengawet, lalu dimasak dalam kuali bersih dengan api sedang dan dilakukan pengadukan berkesinambungan agar tidak terjadi penggumpalan dan hangus (16). Proses dilakukan sampai adonan kental (11), selanjutnya diangkat dan didinginkan (15). Akhirnya bubur saos tomat dikemas sehingga bisa dipasarkan sebagai minuman siap saji, atau dititip jual di kios, rumah makan, swalayan ataupun secara online (17).

\section{HASIL DAN PEMBAHASAN}

\section{Survei dan Pendekatan Tim PKM}

Tim PKK Lut Tawar dan Pegasing Aceh Tengah Nanggroe Aceh Darussalam sebagai Mitra PKM Prodi S1 Farmasi STIKes Indah Medan dan Prodi Farmasi SMK Al Razi Sinar Harapan Medan. Gambar 2 Kantor Dinas KBP3A Aceh Tengah Nanggroe Aceh Darussalam sebagai tempat pelaksanaan PKM.

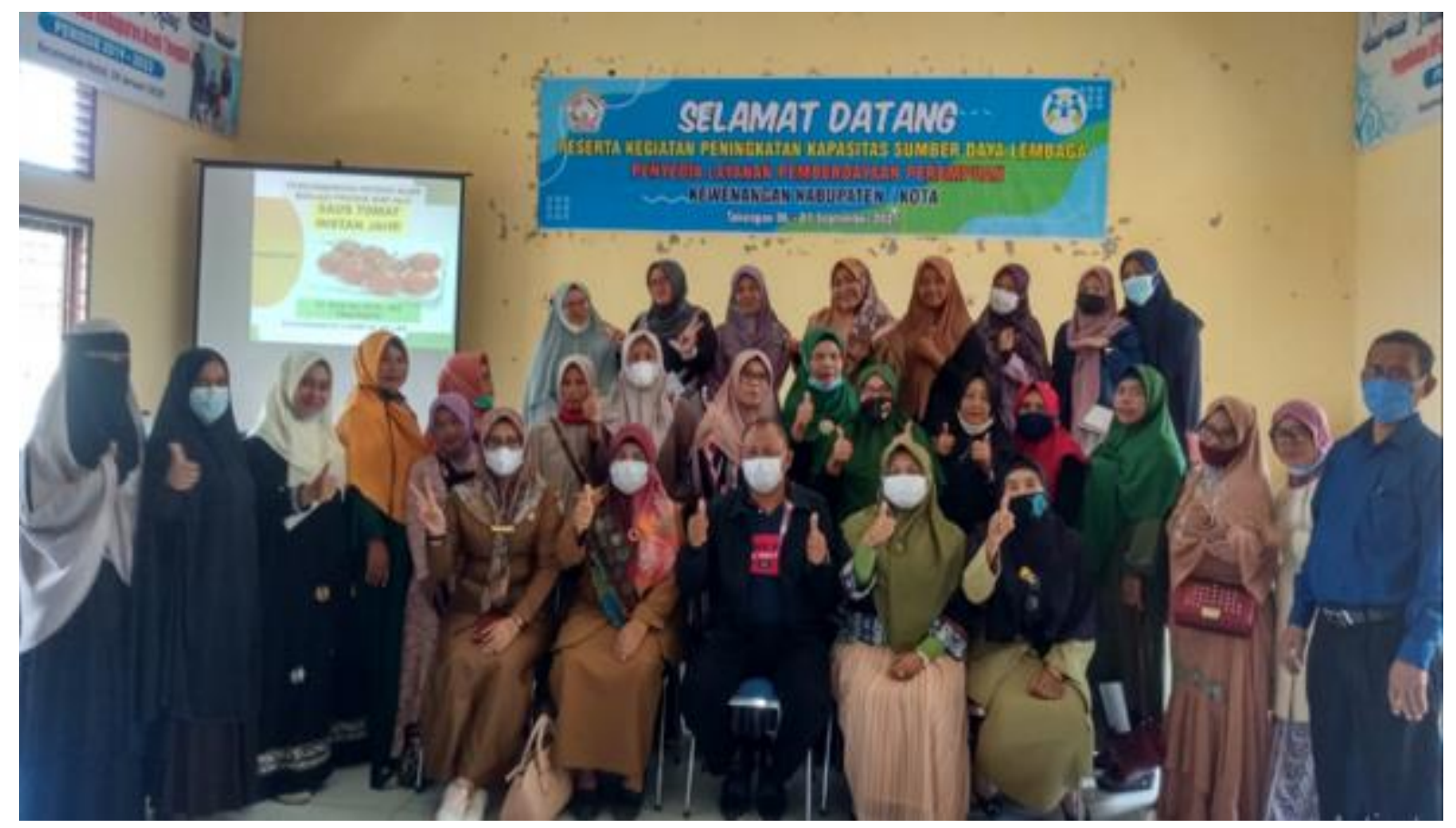


Gambar 2. Foto Bersama Tim PKK Lut Tawar dan Pegasing sebagai Mitra PKM Prodi S1 Farmasi STIKes Indah Medan dan Prodi Farmasi SMK Al Razi Sinar Harapan Medan di Kantor Dinas KBP3A Aceh Tengah Nanggroe Aceh Darussalam

Berdasarkan survei melalui wawancara Tim PKM Lut Tawar dan Pegasing mempunyai kegiatan terbatas bersama suami sebagai petani. Hasil pantauan Tim PKM, IRT berminat dan antusias diberi bimbingan dan latihan pembuatan SAOS TOMAT dengan harapan Perempuan Gayo mempunyai perekonomian yang stabil setiap saat walaupun masa Covid-19. MJI berbahan baku Jahe merah yang didapatkan di sekitar lingkungan tempat tinggal merupakan salah satu solusinya.

Kegiatan PKM tidak ditemukan hambatan hanya ditemukan ketidaksesuaian jadwal pelatihan, karena ada kegiatan lain ibu-ibu Tim PKK selama masa pandemik Covid-19. Kesepakatan tercapai setelah dilakukan komunikasi intensif dan toleransi, kegiatan PKM dapat dijalankan dengan baik.

\section{Kebutuhan Bahan dan Alat}

Pembuatan SOAS TOMAT sangat mudah dan dengan biaya murah, peralatan sederhana, dapat diproduksi ibu rumah tangga anggota TIM PKK Lut Tawar dan Pegasing Aceh Tengah. Bimbingan dan pelatihan memberikan penjelasan biaya pembuatan SAOS TOMAT (Tabel 1 dan Tabel 2).

Tabel 1. Harga Peralatan Produksi SAOS TOMAT

\begin{tabular}{lcrr}
\hline Material & Jumlah (buah) & Harga @ (Rp) & Total Harga (Rp) \\
\hline Ember plastik & 1 & $18.000,-$ & $18.000,-$ \\
Kompor & 1 & $190.000,-$ & $190.000,-$ \\
Tabung & 1 & $110.000,-$ & $110.000,-$ \\
Bahan bakar & 1 & $18.000,-$ & $18.000,-$ \\
Botol pengemas plastik & 160 & $200,-$ & $32.000,-$ \\
Gunting & 1 & $4.000,-$ & $8.000,-$ \\
Pengaduk kayu & 1 & $6.000,-$ & $6.000,-$ \\
Penyaring & 1 & $15.000,-$ & $15.000,-$ \\
Pisau Potong & 1 & $10.000,-$ & $10.000,-$ \\
\hline & Total Biaya (Rp) & & $\mathbf{4 0 5 0 0 0 , -}$ \\
\hline
\end{tabular}

Tabel 1 menunjukkan bahwa investasi alat untuk pembuatan SAOS TOMAT tidaklah mahal, masih terjangkau oleh Ibu-ibu anggota TIM PKK Lut Tawar dan Pegasing Aceh Tengah. Bahkan sebagian alat sudah tersedia di rumah tangga masing-masing, seperti: seperangkat kompor gas, pisau potong, penyaring, gunting dan ember plastik yang biasa digunakan sehari-hari oleh semua lapisan masyarakat. Ini menunjukkan bahwa Ibu-ibu anggota TIM PKK Lut Tawar dan Pegasing Aceh Tengah hanya tinggal mempersiapkan pengemas dan isi tabung gas pada proses produksi.

Tabel 2. Bahan Baku dan Biaya Produksi SAOS TOMAT

\begin{tabular}{|c|c|c|c|}
\hline Nama Bahan Baku & Jumlah (kg) & Harga @ (Rp) & Total Harga \\
\hline Tomat & 5,000 & $5.000,-$ & $5.000,-$ \\
\hline Cabai & 0,300 & $6.000,-$ & $6.000,-$ \\
\hline Bawang putih & 0,300 & 11.000,- & 11.000,- \\
\hline Garam & 0,150 & $500,-$ & $500,-$ \\
\hline Gula & 1,000 & $15.000,-$ & 15.000,- \\
\hline Maizena & 0,080 & $2000,-$ & $2000,-$ \\
\hline Natrium benzoat & 0,005 & $1000,-$ & $1000,-$ \\
\hline \multicolumn{3}{|c|}{ Total Biaya (Rp) } & $40.500,-$ \\
\hline
\end{tabular}

Tabel 2 merupakan rincian bahan baku yang dibutuhkan sekaligus formula SAOS Tomat yang bakal diproduksi. Tabel tersebut menunjukkan bahwa untuk invertasi tidaklah terlalu berat, masih terjangkau oleh masyarakat umumnya atau Ibu-ibu anggota TIM PKK Lut Tawar dan Pegasing Aceh Tengah khususnya. Dalam pelatihan juga disampaikan bahwa komposisi campuran yang setara masih 
dapat diturunkan sehingga biaya bahan baku masih bisa ditanggulangi oleh Ibu-ibu tersebut, misalnya dibagi dua sehingga biaya produksi bisa setengah dari yang tertera pada Tabel 2.

Produksi SAOS TOMAT yang tertera pada Tabel 2 akan menghasilkan bubur SAOS TOMAT seberat 7500 gram. Bahan bakar yang digunakan dapat memproduksi $15 \mathrm{~kg}$ bahan baku Tomat, sehingga total bubur SAOS TOMAT yang dihasilkan $22,5 \mathrm{~kg}$. Kemasan yang disiapkan memuat serbuk seberat $110 \mathrm{~g}$ dengan harga jual Rp 5.500,- sehingga total kemasan sebanyak 160 kemasan dengan hasil jual sebesar Rp 880.000,. Ini menujukkan bahwa Ibu-ibu anggota Tim PKK Lut Tawar dan Pegasing sudah dapat tambahan finansial sebesar $\mathrm{Rp} 408500$,- sekali produksi, karena biaya rutin yang harus dikeluarkan 3 x Rp 40500,- plus Rp 32000,- ; Rp 300.000,- dan Rp 18000 yang masing-masing dari item bahan baku, pengemas dan tenaga kerja serta bahan bakar.

\section{Pelatihan Produksi}

Tim PKM STIKes Indah Medan, dikoordinasi oleh bapak Dr. apt. Samran, M.Si; Ibu Dra. Apt. Elvy Oktima, bapak apt. Suprianto, S.Si., M.Si; bapak apt. Sumardi, S,Si., MSc., Ibu Dr. Apt Cut Fatimah, M.Si., bapak Drs. Apt. Muhammad Gunawan, M.Si, Ibu Enny Fitriani, S.Pd., M.Psi, melaksanakan PKM membagi keterampilan kepada Ibu-ibu Tim PKK Lut Tawar dan Pegasing Aceh Tengah untuk membuat SAOS TOMAT. Bapak Drs Alam Suhada, MM selaku Kadis KBP3A Aceh Tengah beserta jajarannya mendampingi Tim PKM dengan penuh antusias dan memberi semangat kepada Ibu Tim PKK Lut Tawar dan Pegasing Aceh Tengah. Gambar 3 merupakan dokumentasi Tim PKM, Kadis KBP3A Aceh Tengah dan Ibu anggota TIM PKK Lut Tawar dan Pegasing Aceh Tengah.

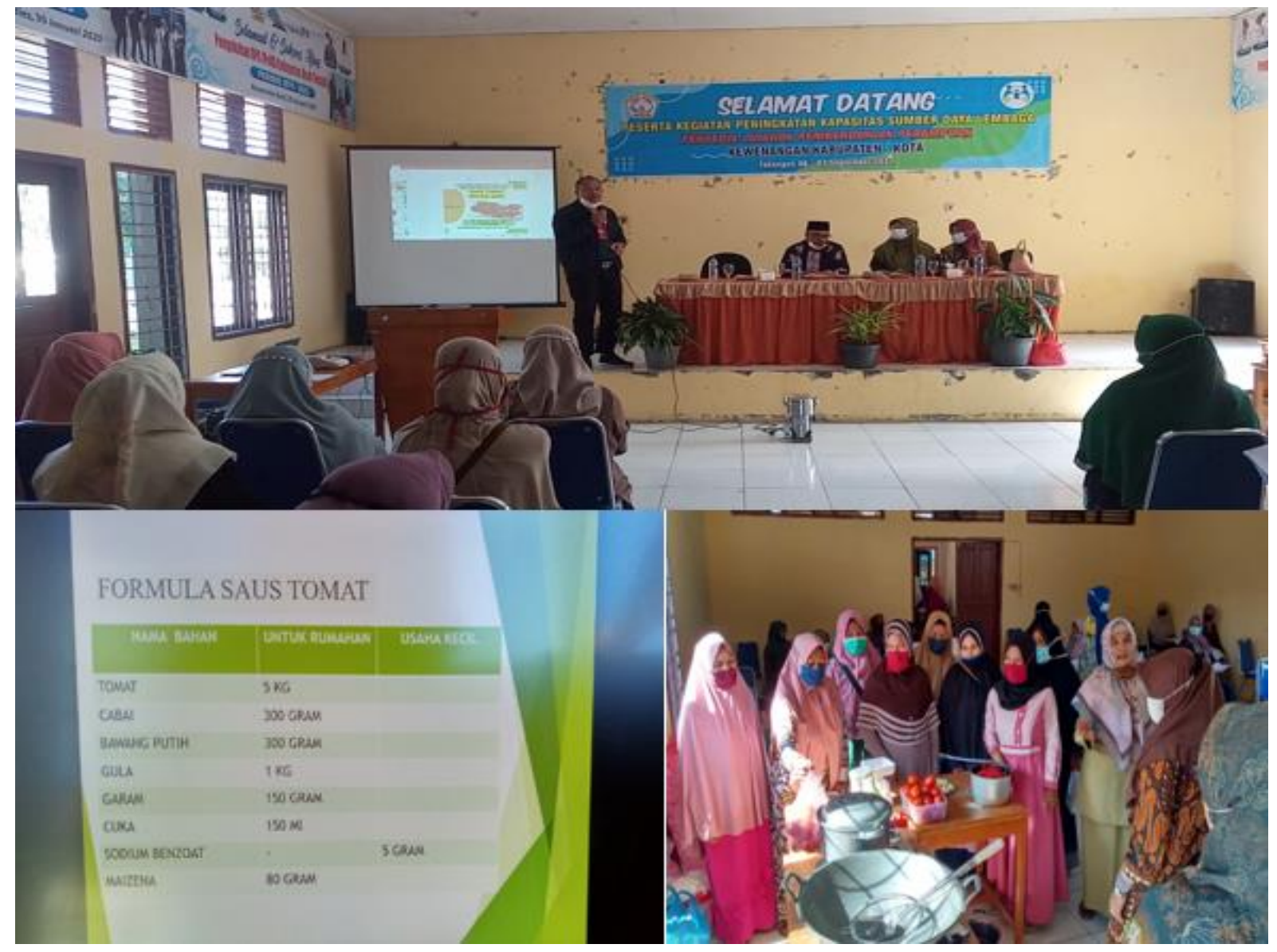

Gambar 3. Tim PKM, Kadis KBP3A Aceh Tengah dan Ibu anggota Tim PKK Lut Tawar dan Pegasing Aceh Tengah, Nanggroe Aceh Darussalam.

Gambar 4 dan Gambar 5 menunjukkan suasana pelatihan produksi SAOS TOMAT. Pelatihan produksi dimulai dari tahap awal sampai menjadi produk SAOS TOMAT dan mengemas produknya. 
Tampak bahwa dalam pelatihan suasana keakraban dan keikhlasan dalam membimbing Ibu anggota Tim PKK Lut Tawar dan Pegasing Aceh Tengah.

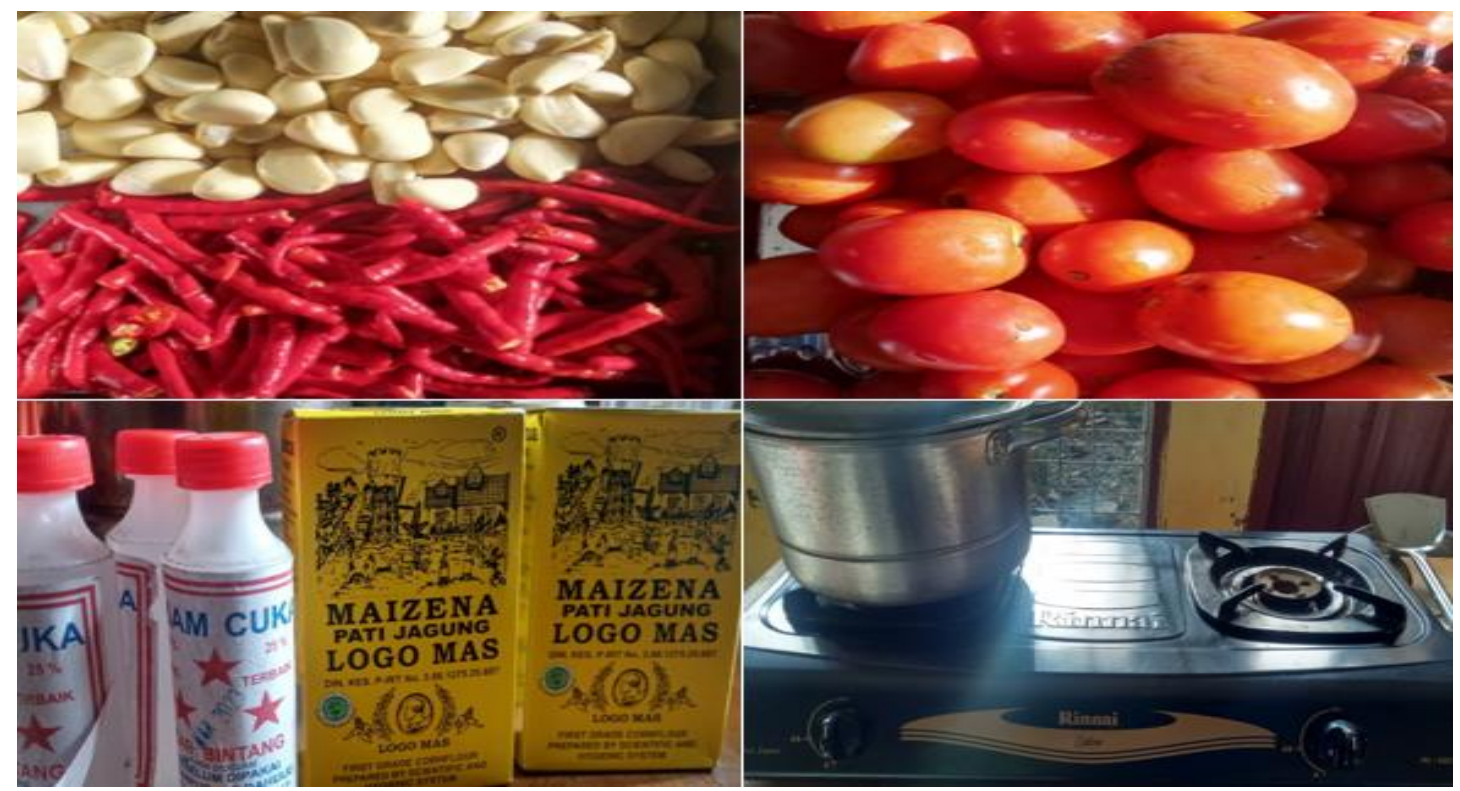

Gambar 4. Tim PKM Memberikan Pelatihan Produksi SAOS TOMAT pada Ibu anggota Tim PKK Lut Tawar dan Pegasing Aceh Tengah

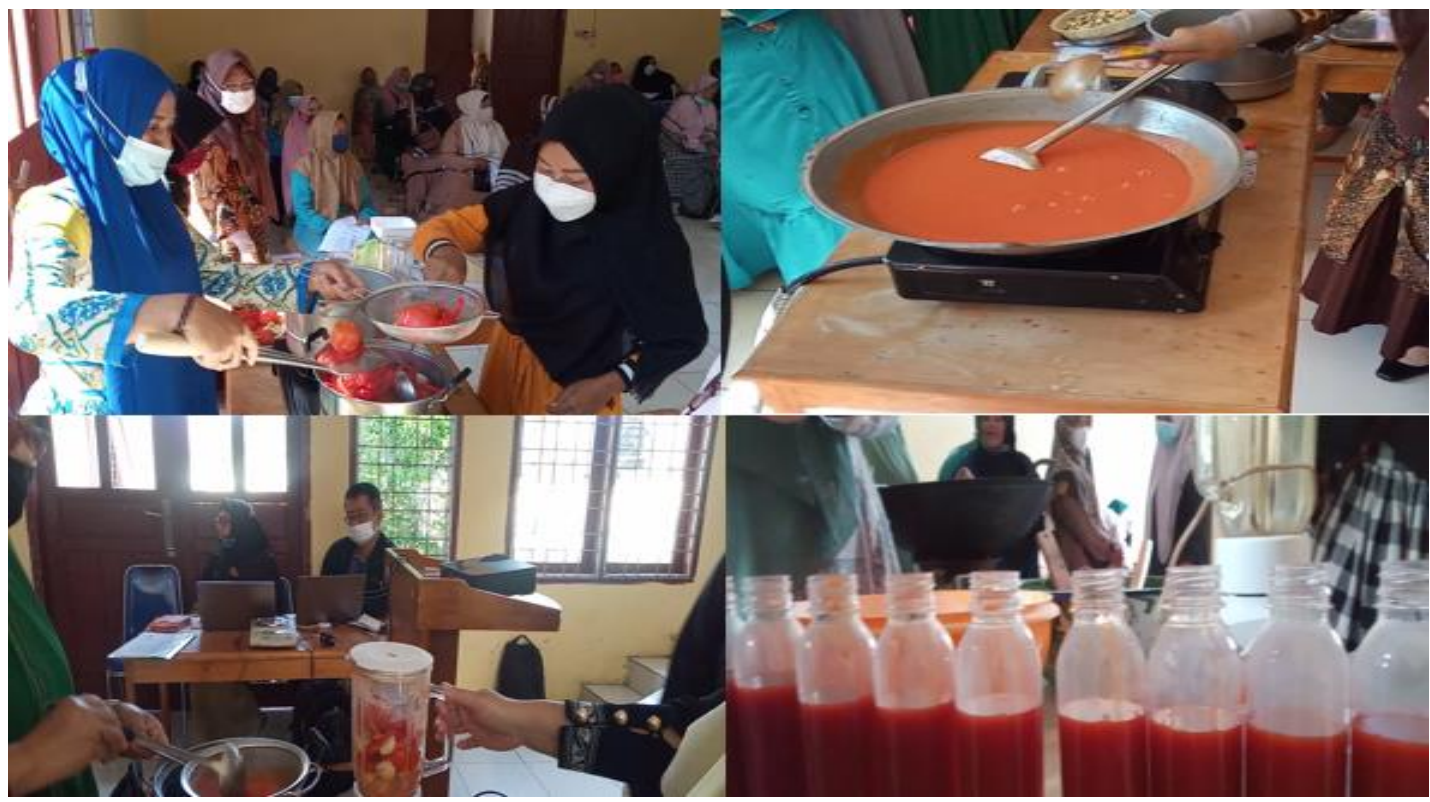

Gambar 5. Ibu anggota Tim PKK Lut Tawar dan Pegasing Aceh Tengah Ikuti Pelatihan Produksi SAOS TOMAT

\section{KESIMPULAN}

Kegiatan PKM telah selesai dilaksanakan dengan hasil sangat dirasakan oleh Ibu-ibu anggota Tim PKK Lut Tawar dan Pegasing Aceh Tengah, karena telah mempunyai ketrampilan dalam pembuatan SAOS TOMAT dan besar harapan dapat menaikkan finansial Perempuan Gayo dimasa Covid-19.

\section{DAFTAR RUJUKAN}

1. Khaironi K, Soesilowati E, Arsal T. Kearifan Lokal Masyarakat Etnis Gayo Sebagai Destinasi Wisata Budaya di Kota Takengon. J Educ Soc Stud. 2017;6(2):99-110. 
2. Tillah RM. Aceh Tengah Racecourse. J Ilm Mhs Arsit dan Perenc. 2019;3(4):43-7.

3. Arinalun TA, Wahyono H. Kajian Daya Tarik Kawasan Danau Lut Tawar sebagai Tujuan Wisata di Kabupaten Aceh Tengan. Universitas Diponegoro; 2018.

4. Sari DP, Kamal S, Hanim N. Komposisi Jenis Plankton di Danau Lut Tawar Kabupaten Aceh Tengah. In: Prosiding Biotik. 2018. p. 108-14.

5. Adhar S, Barus TA, Nababan ESM, Wahyuningsih H, Erlangga E, Khalil M. Estimasi Potensi Produksi Ikan Di Danau Laut Tawar Berdasarkan Morphoedaphic Index. J Serambi Eng. 2020;5(3).

6. Delima CN, Mulyani C, Isma MF. Kinerja Pertumbuhan dan Kelangsungan Hidup Benih Ikan Depik (Rasbora tawarensis) yang Diberi Daphnia sp. dengan Pemberian Pakan yang Berbeda. J Ilm Samudra Akuatika. 2021;5(1):17-26.

7. Syahputra B. Atasi Permasalahan Harga Tomat, Aktivis Gayo Desak Pemerintah Aceh Bangun Pabrik Saos. RRI Takengon. 2021;

8. Hadi S, Sita BR. Produktivitas dan Faktor-Faktor yang Berpengaruh terhadap Produksi Usahatani Tomat (Solanum lycopersicum Mill) di Kabupaten Jember. J Soc Agric Econ. 2018;9(3):67-78.

9. Afridila S. Analisis Sikap Toleransi Petani Tomt terhadap Resiko Usaha Tani Tomat di Kabupaten Bener Meriah dan Kabupaten Aceh Tengah. ETD Unsyiah. Universitas Syah Kuala; 2018.

10. Taufiq FM. Harga Anjlok, Tomat di Takengon Berlabuh ke Tempat Sampah. Lintas Gayo Media. 2016;

11. Saloko S, Handito D, Rahayu N, Rahman S, Dwiani A. Pengolahan Tomat Menjadi SaosTomat. J Pendidik dan Pengabdi Masy. 2019;2(2).

12. Heriani N, Abbas Zakaria W, Achdiansyah S. Analisis Keuntungan dan Risiko Usahatani Tomat di Kecamatan Sumberejo Kabupaten Tanggamus. Jiia. 2013;1(2):169-73.

13. Wandestri W, Hamzah F, Harun N. Penambahan Beberapa Konsentrasi Xanthan gum terhadap Mutu Saos Tomat (Solanum lycopersicum Lin.,). 2016;3(1):1121-2.

14. Sjarif SR, Apriani SW, Riset B, Manado SI. Pengaruh Bahan Pengental pada Saus Tomat. J Penelit Teknol Ind. 2016;8(2):141-50.

15. Dwiani A. Pengolahan Tomat Menjadi Saos Tomat Pada Ibu-Ibu Rumat Tangga di Kebun Duren Kelurahan Selagalas Kecamatan Cakranegara Kota Mataram. Alamtana J Pengabdi Masy. 2020;1(1):1-5.

16. Samran, Suprianto, Sumardi, Nasution F, Laia FDR, Lantika FD. Pelatihan Pembuatan Minuman Sehat Jamu Instan Kering (MSJIK) bagi Ibu PKK Desa Cinta Rakyat Percut Sei Tuan. Mejuajua J Pengabdi pada Masy. 2021;1(1):11-7.

17. Asnamawati L, Rasoki T, Novrianda H, Kristanti D, Nurmalia A. Pengenalan Nilai Tambah Melalui Pengolahan dan Pemasara Saos Tomat Di SMK Agribisnis Dangau Datuk Bengkulu. Din J Pengabdi Kpd Masy. 2021;5(2):488-93. 